\title{
Monastic retreat and pastoral care in the Dutch Reformed tradition
}

\author{
C H (Kaaiman) Schutte \& Yolanda Dreyer ${ }^{1}$ \\ Department of Practical Theology \\ University of Pretoria
}

\begin{abstract}
Of late, there has been a growing interest in retreat among clergy and members of congregations in the Dutch Reformed tradition in South Africa. The article investigates the relevance of the monastic traditions for this growing interest in Reformed circles. It focuses on aspects of retreat such as the role of holy places in the monastic traditions (e.g., monasteries, cathedrals, retreat centers) and the experience of silence, solitude, regeneration, divine presence and spiritual formation. Proceeding from an epistemological reflection on the subject as described in a previous article, the aim of this article is to explore the "action of retreat" as a narrative research journey and pilgrimage in order to investigate the relevance of the Benedictine, Franciscan and Taizé monastic-mystic traditions (seen as an associative/mystic spirituality) for retreat in the Dutch Reformed tradition (which is seen as a disassociative/rational/ dogmatic spirituality).
\end{abstract}

\section{INTRODUCTION}

This article assumes that "monastic retreat" - though a relatively new phenomenon in the Dutch Reformed tradition - can become a source of regeneration and healing. Yet, such an assumption can only be substantiated by bringing monastic spirituality in critical dialogue with the kind of spirituality found in the Reformed tradition, specifically within the Dutch Reformed churches in South Africa. However, this is not the scope or intent of this article. This article aims rather to be more exploratory in nature and should be read in connection of a previous one (see Schutte \& Dreyer 2006:965-982). In

\footnotetext{
${ }^{1} \mathrm{C} \mathrm{H}$ (Kaaiman) Schutte (PhD) is pastor in the Dutch Reformed Church Murray (De Doorns), South Africa. This article is based on his $\mathrm{PhD}$ degree in Practical Theology at the Faculty of Theology, University of Pretoria, entitled "The relevance of the Benedictine, Franciscan and Taize monastic traditions for retreat within the Dutch Reformed tradition: An epistemological reflection", completed under the supervision of Prof Dr Yolanda Dreyer.
} 


\section{Monastic retreat and pastoral care}

the previous article some postmodern epistemological theories were looked at in order to provide a mental framework, models and methodology to investigate retreat as "communicative action". Such action enabled the researcher to enter into a narrative inter-dialogue with retreatants. The "action of retreat" was described in terms of a social constructionist model in which the method of qualitative interviewing played a significant role in the "narrative research journey" with retreatants. The purpose of this second article is to report results that can be relevant for retreat in the Reformed tradition. Regular retreats - both personal (private) and group retreats - can be an effective way of creating the space and time to receive God's healing for brokenness, God's presence for emptiness, God's companionship for loneliness and God's enabling strength for ministry (see Menken-Bekius 2001:61-105; cf Lukken 1999:61).

The research indicates that the monastic "way of retreat" and "way of life" is holistic and health-generating. Pilgrims are invited to look honestly at their painful stories and wounds, and are given the opportunity to open their hearts to God's unconditional ever-embracing love. Roberts (1994:xiv-xv) states that stories are central to therapy and have the potential power to link people together as well as to pull the events of their lives together. Narratives provide a versatile tool for reflecting on where they have been, where they want to go, as well as for creating a collaborative therapeutic relationship. Capps (1998:30) puts it as follows: "Stories are relatively simple formats that illuminate complex interaction patterns." Stories can locate people in their lives, reveal where they come from and articulate central values and themes. Stories from the past may provide a foundation for new stories, new beliefs, and ideas to be shared. The understanding through the stories that people tell, as well as ongoing dialogue about the new stories being created, can help pilgrims to deal with the past and move on with the present and into the future (Roberts 1994:7). People find their identities, by telling and retelling their stories (see Shea 1982:23-43; cf White \& Epston 1990:10-11). The atmosphere and environment of a retreat facilitate the interpretation and new understanding of the life-story of retreatants. Monastic spirituality reminds pilgrims that they are not alone with their stories of anguish and pain, but are part of a compassionate community of wounded healers who reach out to comfort them. The way in which the monks live in community and compassion creates the regenerative atmosphere within which this process can take place.

Nouwen (1990:25) regards solitude during a retreat as a "furnace of transformation." It provides a way for caregiver (spiritual director) and retreatant to understand and articulate their inner worlds. Being alone with the 
Alone brings pilgrims closer, deeper into the healing presence of God.

Solitude may provide a way for the spiritual director and retreatant to understand and articulate their inner world. Many retreatants experience the prayer of tears when their breathing, heartbeat, metabolism, brain waves, blood pressure and the tonality of consciousness change in the solitude of mediation. During the phases of solitude coupled with silence, meditation, and an encounter with God, some pilgrims (Nouwen 1990:13-14; cf Müller 1996:32-37) experience deep insight into inner "demons" and pain. De Waal (1989:21) states, "We all stand in need of healing, we are all seeking wholeness." The retreat venue, the silence, meditations and prayers provide a healing, transparent atmosphere of truth and honesty, as well as an authentic awareness of God's presence in oneself and in fellow retreatants. In meeting one another, being there as you are and the others as they are, and in the presence of God, the sharing deepens and the light each person receives from God shines forth more brilliantly and in a healing way.

\section{MONASTIC RETREAT AND THE PRESENCE OF GOD}

Monastic retreat is a commendable, or even for some pilgrims an "essential" way to become aware of and experience the presence of God. The pilgrims indicate the main reason for going on retreat as: to be in the presence of God; to draw closer to God; to have a spiritual experience of moving deeper into God's presence. The mystery of Christ and his unfathomable riches is the "main attraction". Pilgrims are attracted to the monastic parable of celibacy, commitment, compassion, dedication and ritual. They responded to it with a sense of the mystery of the Absolute. A growing interest in spirituality, a hunger for the mystery, the presence of the uncontrollable Source rather than dogma, faith, religion or church denomination, is what brings people to the different overseas monasteries I visited and also to monastic type retreats in South Africa. Retreat facilitates a way of going beyond mere knowledge of God and religious truths to the experience of God and truth. There is a growing yearning for a greater deeper meaning in life, for something beyond material success and scientific achievement. Spiritual experience can provide such deeper meaning. Over the years there has been, according to Ware (1995:113), a strong move towards the affective or spirituality of the heart, away from the intellectualism of many mainline churches and a growing trend toward the mystic as part of a corrective process towards balance or towards a more integrative spirituality .The "inner advance" or "journey to the inner mountain" is gaining momentum in the hearts of pilgrims and monasteries and retreat centres. The experience of the desert (see Merton 1960:3-8; Nouwen 1975:32-35; Chittester 1990:23; Waaijman 2000:262-265) helps retreatants to 
become quiet, alert, more perceptive and reflective. In the process, certain issues become clearer and reality more becomes more recognizable and unambiguous. A relevant question would be if man and woman are able to live an authentic holistic spiritual life without a desert experience or elements of desert (monastic) spirituality in a dehumanized, deluded and denatured world. An authentic experience of enlightenment leads retreatants beyond the Scriptures to that to which the Scriptures attest. "It is like a match that can be thrown away after it was used to light the fire" (Jäger 1987:73). Sacred texts, rites, recitations, ascetics, solitude and the practice of lectio divina prepare retreatants for an awakening to the reality of the Infinite. The experience opens windows to the mysterious, mighty, sovereign God and God's very real presence.

\section{RETREAT AS RITUAL AND RITE OF PASSAGE}

There are definite similarities between retreat as pilgrimage and ritual, and the structure of rites of passage. This is relevant for the planning, experience and understanding of a meaningful retreat. Retreat and pilgrimage in essence follow the structure of rites of passage (Van Gennep 1960:1-25; Turner 1969:223-226, 99-101, 251-260) and a ritual process of status transformation during phases of transition. Turner's (1972:238, 240-241; 1977:106-107) conceptualization of separation, marginality (liminality-commmunitas), reincorporation, and especially structure and anti-structure (liminality) is a helpful tool for planning and analysing retreat, as well as for understanding the process and experience of monastic retreat as ritual. Ritual may emphasize either structure or anti-structure. These categories are useful for determining what the rituals would be like during retreat, how symbols would be used to express meaning in the ritual, and what kind of atmosphere and framework for the retreat as a whole, would be relevant. To go on retreat essentially means to withdraw and interpret, reflect and meditate, leaving structure behind and moving into communitas-liminality (Turner 1969:96, 149; Turner 1977:96; Harris 1992:57).

Retreatants are given an invitation or opportunity to experience the mystery of God and to be alone at times or to spend time with fellow pilgrims. A clear break with the usual structures and pressures of life, such as those of the city, church, work and home environment, takes place. The retreatant departs to another venue and a different way of being, usually in scenic surroundings (e g, nature, gardens, a chapel). Away from their previous habits, schedules and actions, pilgrims are encouraged to contemplate on their society, the cosmos, and the powers that generate and sustain them. Liminality is also a stage of reflection, in this case reflection on the sacred, esoteric, mysteries of life, and the supernatural (Turner 1972:238, 240-241; 
Turner 1977:95). The spirituality and faith stories of the Dutch Reformed pilgrims on retreat in South Africa revealed a growing trend to mystic spirituality as preferred spirituality. The opposite of the structural, verbalrational, sequential, orderly, language and action mode of the modernistic paradigm, until recently so characteristic of the Dutch Reformed tradition, is the intuitive, tacit, less "neat" and more mystical mode of a postmodern paradigm. This shift is regarded by psychologist Arthur Deikman (1982:481489) as essential for a person to be able to have a mystical experience. I agree with Ware (1995:34) that the analytical, reflective thinking of Western culture and theology tended to neglect experiential awareness of God's presence. This, in turn, limited ways of knowing in the liminal sense of the word and made mystic experience into something "accidental." Inner mountain, authentic prayer and the experience of God's presence occurr during the retreats which enable retreatants to enter into a receptive, mystical, anti-structure liminoid mode.

Silence, cherished by monastic spirituality as oxygen for the inner fire of the Spirit of God (Cowan 2002:67; see De Dreuille 2003:23; cf Keating 2003:90), plays an important role during this phase of the ritual and the betwixt-and-between period becomes a time of fruitful darkness. Ritual liminality has the power to soften the rigidity of social structures and its communal activity suggests new patterns for social existence and provides energy to resist oppressive ideological power structures (ScandrettLeathermann 1999:314-315, 324). Rituals are a fusion of powers and a mobilization of energies that may establish powerful, pervasive, and longlasting moods and motivations (Turner 1973:1100-1105). Menken-Bekius (2001:61-105) emphasizes the potential worth and healing impact of ritual in the pastoral context and emphasises how daily and other rituals are part of being human. Ritual as a way of expressing oneself can become a vehicle by which to come to know oneself better or to rediscover life and the meaning of life, or how to depart from life in a meaningful and dignified way. Through ritual people invite the supernatural, the regenerating power of the mystery into their lives (see Lukken 1999:61). Ritual structures people's lives within time and space and provides a bridge between the inner-world of emotions, passions, and desires and the surrounding outer-world of actions, people, and environment. The "dying moments" (for example dealing with bitterness, guilt, forgiveness) type of ritual as one element of the monastic retreats I have directed, as well as the "kneeling with the head on the cross" ritual at Taize, have a psycho-hygienic (term used by Menken-Bekius for the healing/therapeutic function of ritual) function in the lives of pilgrims. The fact that silence and longer periods for meditation and reflection on stories are provided for, whilst taking part in the ritual of retreat and other sub-rites, 
facilitated the powerful creative potential by way of imagination. MenkenBekius (2001:66) stresses the importance of the imagination in secular and religious ritual and says "wat betreft de religieuze rituelen acht ik het een van die belangrijkste verworvenhede van de moderne theologie dat ze de betekenis van de verbeeding heeft (her)ontdekt." After the retreat, many pilgrims report a feeling of renewed energy and motivation to view life in a different light. Others plan of to make significant changes and decisions in their lives.

When planning a monastic retreat, it is commendable to make antistructure the primary goal of the monastic retreat experience. Relational antistructure (communitas) can be emphasised, for example, during Eucharist, group discussions and feedback on spiritual matters, as well as during the opportunities for more playful interaction between retreatants. The emphasis can be on liminality during prayer times and lectio divina in the chapel, dying moment rituals and silent solitude outside. In planning retreats I deliberately chose to develop a monastic type of retreat for those seeking God and God's presence in a different way (mystic-monastic), to have union and communion with God, to be alone with God before returning to their daily lives (focusing on liminality). Flowing from the atmosphere of silence, solitude, meditation and being with the ultimate Mystery, time was also given for open and relational-communitas type discussions and for reflecting on and sharing of the stories of their lives.

\section{RETREAT, PILGRIMAGE, AND HOLY PLACES}

There is a growing popularity of pilgrimages (retreats) to "holy" places (Malloy 1998:2-25). The concept of pilgrimage in the broad sense of the word refers primarily to a person on the way to, a passing guest travelling towards new horizons, who undertakes a personal adventure to a holy spot or, for that person, a sacred place. Pilgrimage (making one's way to holy places) as an ascetic (premodern) practice may be helpful for Christians to find healing or to experience a deepening of faith through the difficulties and devotions of a temporary exile, and by coming into contact with the divine, obtaining grace at the pilgrimage site or offering gratitude there (Skar 1985:89; cf Morinis 1981:282). A spirit of community is an integral part of pilgrimage. Yet the pilgrim is also utterly alone because the journey is not only to a physical place with others, but into the individual's soul. The pilgrim is no ordinary traveller and his or her map is in the heart. Pilgrimage is a communal rite of passage through space, at home and away from home, a journey to a sacred place (see Turner 1972:234-245). It serves as metaphor for the inner journey to the inner mountain. 
Since the 1960s many Christians (especially young people) have been flocking to Taize as pilgrims. Many of them were disillusioned with religion. Some went as post-modern pilgrims with a pre-modern passion, a renewed interest in the metaphysical and the parable of community and reconciliation which manifests among the Protestant and Catholic brothers who live there. The numbers are still growing today and these pilgrimages continue to influence the lives of the people and their communities after the retreat. Taizé is a "spiritual success story" because of the atmosphere, "holy place", and monastic way of life. There are also a growing number of pilgrims who go to Benedictine and Franciscan monasteries for retreat experiences. Pilgrimage to the monasteries is an invitation and a challenge to detachment, to be constantly on the move together with the pilgrim-God and fellow pilgrims. It is about nourishing, nurturing, evoking an alternative perception and consciousness to those dominant in culture and society.

Interviews with pilgrims at Taize, especially young people, revealed a thirst for communion with God and fellow pilgrims, a thirst for freedom from religious and ideological powers and blind conformism, as well as for radical authentic commitment, as symbolized for example in the full-time community way of life of the brothers. To go on retreat is an invitation to enter into a place or a dimension of stillness, solitude, and prayer. This place is in the heart or in a monastery, garden, retreat centre, or chapel reading. It can be where one is meditating on the word of God or where the Eucharist is offered and received. The in-dwelling of God is continually experienced within the innermost heart.

The research narrative contains the witness of pilgrims to life-giving and life-enriching moments at places to which they pilgrimage on retreat. The experience of the researcher and pilgrims interviewed, is that the holy land, monasteries, cathedrals, retreat centres and mountains visited over time, exude power, holiness, silence and the mysteries of God. To be able to add personal prayers, solitude and silence to those of the people who live there or who have visited over the years, becomes a special spiritual experience. These places, filled with Gods' mysterious presence and with God's people, provide powerful contexts for inner transformation. The challenge for the pilgrim is to return home and implement this greater understanding or significant experience. The pilgrimage to sacred places may have the paradoxical effect of enabling pilgrims to be more profoundly at home than before culminating in a new way of life.

\section{ELEMENTS OF MONASTIC RETREAT}


There are main elements ("ingredients") of monastic retreat, which make it a worthwhile, meaningful and an effective doorway through which to move deeper into the Ultimate Mystery.

Monastic retreat is quite different from other ways of retreat. One such other possibility is, for example, a church camp type retreat with a big conference hall, dormitories, Bible study group discussions, other group interaction and small group activities, playing games, singing and talking, lively worship songs, laughter and playing. Another is a charismatic type retreat which could be fairly noisy and wordy, focusing on the gifts of the Spirit, on praise and worship, Bible teachings on the Holy Spirit, proclaiming prophecies and intercessory prayer. A monastic type retreat at a retreat centre or a "Holy Place" (monastery) has a different atmosphere created by elements such as, for example, a chapel or cathedral, specific divine offices or prayer times in the chapel, ample time for silent meditation, listening prayer, being alone and being together with others before God, short Bible meditations, more time to spend alone with God, longer periods of silence alternating with shorter periods for group discussions, relevant ritual and symbolic actions. The style of worship is subdued and this is enhanced by meditative music. The main elements of monastic retreat, namely silence, solitude and lectio divina (lectio, meditatio, oratio, contemplatio) open the doorway to a journey deeper into God and into the inner sanctuary (Cowan 2002:55; see Keating 1982:4; 2003:90-97, 145, 147; cf Merton 1956:261; 1971:42; Casey 1994:4-8). God is the quest, to be alone with the Alone, silent before and embraced by divine Mystery (Steere 1967:100).

There need not be a "final formula" for a retreat or only one type of retreat, nor is there necessarily such a thing as one "ideal setting" for a retreat. Creative varieties of different ways of retreat at various venues may be meaningful for retreatants. Monastic retreat is but one approach. Within the monastic approach of conducting a retreat, there are also a variety of possibilities and different combinations of elements that may be implemented. In most of the monastic retreats which formed part of the research journey, the main elements were silence, solitude and lectio divina.

\section{MONASTIC TRADITIONS AS WAY OF LIFE AND WAY OF RETREAT}

The differences and similarities between the Benedictine, Franciscan and the Taize ways of retreat and ways of life provide an inspiring model for the Christian pilgrimage and can especially be utilised to enrich the Reformed tradition. A "rule of life" or guidelines for a specific way of life is common in the Benedictine, Franciscan, and Taizé monastic traditions. Many Christians 
worldwide who live outside of monasteries have opted to follow the basic principles or monastic rhythm in their own lives. Examples of this are, for instance they way of life of St Benedict, or St Francis, or the Source of Taize which was developed by Brother Roger. Carefully prescribed rituals, gestures, words, elaborate ceremonies and liturgy, make up life in a monastery. The monks dedicate themselves to a life of prayer and constant communion with God. There is strict discipline in such a way of life. A monk in the La Pierre Qui Vire monastery, for example, lives his life, day and night, in obedience to St. Benedict's Rule. The Rule is safe-guarded and interpreted with the utmost discretion and consideration by the spiritual father of the community, the abbot. The function of the Rule is to reveal the beauty of prayer and contemplation and to allow them to be fully practiced and experienced with authentic peace and joy. The monk and the community who wish to make their life one of continuing prayer and monastic mindfulness, can only do so within a concrete daily schedule which supports this goal. At the La Pierre Qui Vire Benedictine monastery, for example, the celebration of the Eucharist, the communal psalmody, individual meditation, study, manual work, eating in silence, sleeping, and the seven communal prayer offices (Divine Office) every twenty four hours, are all subject to careful regulation and conscientious observance.

While participating in the life of the monastic discipline, pilgrims sense and experience the mystery of God. Prayerfully they become more aware of God's presence, which is sometimes experienced as hidden and veiled, while at other times it becomes more visible in the daily rhythm of the contemplative way of life. A way of life or rhythm for daily life after/between retreats is a valuable source by means of which to live a life of prayer, to become more conscious of God's presence and to grow and persevere in a life of monastic mindfulness (awareness). When the relevance of the monastic way of life for the Dutch Reformed tradition is discerned by exploring insights gained from the Benedictine, Franciscan, and Taizé traditions, it is necessary to take into account each pilgrim's unique spirituality, needs, life-stories, environment, abilities and church tradition.

\section{A MONASTIC WAY OF LIFE AND THE DUTCH REFORMED TRADITION}

The rules of the respective monastic traditions (from a premodern context) provide a valuable source for constructing a way of life in the Dutch Reformed tradition (a modern and postmodern context).

The research journey identified a need amongst retreatants or pilgrims to receive further guidance on the journey after or between retreats. A rule or 
practical framework could become a tool to live by. The rule reflects the main principles of the gospel in a monastic way. Without directions for the way, the pilgrimage through life can become fragmented, not sufficiently focused on the Centre, the Ultimate Mystery and Source of Life. A spiritual rule or way of life could function as an ark of human and eternal values which can bring people safely to land and also provide possibilities for sailing safely on the, at times, stormy seas of postmodernity.

The following elements could become part of a "rule of life" for people in the Reformed tradition: weekly communion, contemplative prayer two to three times a day, penitence or self-examination, seeking spiritual direction (confession, guidance), work, study, spiritual awareness or monastic mindfulness and deeds of mercy. Going on one retreat annually, either for a weekend or for a three day directed retreat and in addition to go for shorter retreats (directed or non-directed) or to enjoy a quiet day of reflection every once in a while, can be a good booster. In everyday life Christians in the Reformed tradition can continue with their usual Bible study and group discussions, while in addition reading up on the classical spiritual disciplines and monastic spirituality. Borrowing form this kind of spirituality Christians in the Reformed tradition will greatly add to the quality of their lives and faith experiences when they make monastic values such as simplicity, charity, mercy and hospitality part of their lives. "Downshifting" or living at a slower pace with less focus on materialistic things as core goals will also bring a Christian life more in line with the gospel. Following the monastic way of continually practicing to experience God's presence, being more alert and attentive to God's presence even during busy schedules, deadlines or routine and mundane tasks will contribute to a deepening of one's faith. Other monastic principles and values such as a sense of accountability or obedience, humility, trust, discipline, humour, responsibility and peace in the living out of the rule can be fruitfully explored by Reformed Christians. Consulting someone on a regular basis for direction, mentoring, reflection and self-evaluation, has not been part of Reformed spirituality, which was often practised in isolation as something very private. By breaking the isolation the faith of Reformed Christians can benefit from an outsider's perspective as well as from just spending the time to reflect on one's faith rather than just taking it for granted and becoming entangled with the issues of everyday life. Being part of a community of Christians and worshipping with others have always been an integral part of practising faith in the Reformed tradition. This can be expanded with meditative or silent type of meetings. In this way Reformed Christians who have elected to follow a monastic way of life, can maintain contact with one another and share their journeys in open communication. 
Adopting a rule of life or commitment is really nothing more than explicating, elucidating, and applying the principles of the gospel in one's personal and communal life. They are not meant to be adhered to in a legalistic way. The research narrative has shown that a rule of life for Christians in the Dutch Reformed tradition may fill a need for those who wish to live daily in God's presence in a more disciplined and monastic-associative way. A rule could facilitate a way of life where spontaneity, spiritual discipline, commitment, joy and simplicity in the presence of the Divine Mystery are channelled toward the greater good, adding more value not only to the personal life and faith of the individual participant, but also and especially to the lives of others.

\section{AN ECUMENICAL POSTSCRIPT}

Ecumenism is not a prerequisite for retreat but the model of ecumenical community and reconciliation at Taizé underlines the high value of ecumenical retreat. Ecumenism at Taizé manifests not so much in the domains of theology or doctrine, but in spirituality and worship (see Schutz 1990:49-50, 59-60). The Taizé ecumenical community of priests (brothers from Protestant and Catholic traditions) where thousands of pilgrims visit every year, is fully ecumenical. The pilgrims who go there for retreat come from all over the world and represent Evangelical, Catholic, Orthodox, Reformed and other traditions. The basis and vital core of the ecumenical experience on the Taizé hill is not dogma, creed or theology, but prayer (the daily Divine Office in the Church of Reconciliation) as communion with God, the Source of Life and the Source of communion between human beings. The cross-fertilization of insights from the different church traditions represented there (e g, evangelical warmth, zeal, enthusiasm, personal redemption experience, Catholic sacramental mystical life and the idea of sanctification by the church, and Eastern Orthodox liturgy steeped in ritual and symbol) add value to the retreat experience of the pilgrims. People from various traditions and denominations express the desire to find and experience God, or to venture deeper into God's presence. 


\section{APPENDIX $1^{2}$}

Questions to pilgrims at the beginning of a retreat for example at Taize

- Name, address, nationality, country or city, church affiliation or tradition

- Please share with me aspects of your spiritual story or journey up to now?

- Have you been on a retreat before?

- Is it your first retreat of this kind e $g$ at Taize?

- Why did you come, why are you here?

- Are there specific needs to be fulfilled or expectations to be met whilst you are here? What are they?

Questions asked during or just after the experience

- How would you describe your experience of this retreat at this stage?

- What about more specifically the prayer meetings, music, silence, place, atmosphere, silence, solitude, group discussions etc

- Were your expectations met or not? Why?

- Would you say, "This was a meaningful and worthwhile experience for me" or "This was not a meaningful or worthwhile experience to me".

Explain or describe your answer

- If you have been to other retreats before, compare it with this one

- Are you taking back something with you after this or not? Any decisions made or goals because of it? If so, could you describe it please?

Interview questions put to Franciscan monks at Sacro Convento di San Francesco in Italy, Assisi

- Name and background

- Please tell me the story of your walk or journey with God

- How did it happen that you became a monk of the Franciscan order?

- How would you describe, what is monastic spirituality for you?

- What would you say is the heart of Franciscan spirituality?

- How does it compare to other monastic traditions for example Benedictine or Taize orders? Similarities and differences

- How would you describe the role of this community within the broader town of Assisi e.g. the poorest of the poor, and local churches/parishes?

- Would you describe this Basilica or Holy Place as a sort of retreat centre? Do people come here as pilgrims to spend a few days here and why?

- How do you see the role or function of retreat in our modern society?

- What is that attract people worldwide to Franciscan spirituality?

- How would you describe your way of life within this specific order, and in what way do pilgrims become part of it while here? What do you think are the impact or influence of the liturgy or prayer times on pilgrims?

- Has monastic life and holy places something to offer society today? Could you elaborate on it?

\footnotetext{
${ }^{2}$ Readers who want to see the questionnaire can approach Dr Kaaiman Schutte at kaaiman@absamail.co.za
} 
Interview questions put to Benedictine monks at La Pierre Quie Vire

- Could you please you tell me more about the history of this monastery.

- From the moment, I arrived here at the monastery I was welcomed in a very special and hospitable way by one of the brothers at the door and has experienced so much love and kindness despite language barriers. Is this the way everyone is welcomed and treated who knocks at the huge door of $\mathrm{La}$ Pierre Qui Vire?

- Is it very different from the other Benedictine orders and in what way I

- Tell me more about the presiding Abbot, how is he elected and what is his role and function within the community?

- Could you explain the liturgy or seven prayer offices everyday in the chapel?

- How does Benedictine monastic spirituality view prayer and does your tradition offer a particular way of praying that is also practiced here?

- What to your mind is the main characteristic of the life of a Benedictine monk?

- I noticed that the brothers here are involved in a variety of activities or work. How do monks view work within the context of a monastery and retreatants that come here?

- I also noticed that this monastery is a very quiet place, silence at mealtimes, brothers using words sparingly and an atmosphere of silent reflection. Could you elaborate on/respond to this observation?

- Why would you say are many people drawn to monasteries and retreats and why to this specific place?

- Would you recommend retreat to all people?

- What is your personal view on retreat?

Interview Questions put to Dutch Reformed pilgrims in South Africa

- Name:

- Address:

- Nationality:

- Country:

- City:

- Occupation:

- Church affiliation or tradition:

- Have you ever been on a retreat before? Where and when did it take place?

- What did you experience there?

- Why did you come, why are you here?

- Are/were there specific needs that you want to be fulfilled or expectations to be met whilst you are here? What are they?

- What about the specific venue where retreats are held, is the place important to you or not at all?

- How would you describe your experience of this retreat?

- What about more specifically the Divine Office (prayer meetings) music, silence, place, atmosphere, music, solitude, group discussions, icons, colours, ritual, etc. Could you elaborate on it please

- Were your expectations met or not? (Why or why not?) 
- Would you say, "This was a meaningful and worthwhile experience for me" or "This was not a meaningful or worthwhile experience to me".

Explain or describe your response

- If you have been to other retreats before, how do you compare it/them to this specific experience?

- Are you taking back something with you after this or not? Any decisions made or goals because of it? If any describe it please

- Any other input or response you would like to give?

A narrative interview

Could you please tell me the story of your spiritual journey and how it enfolded over the years up to now at this retreat, you may start as far back as you wish?

Interview schedule with brothers at Taize

1. What would you say is at the heart of the pilgrimage of Taize?

2. Why has Taize became so popular over the years, especially amongst young adults from all over the world? What is the attraction?

3. Why do you think do young people even the not so religious ones become so easily immersed into the monastic atmosphere and feel at home here?

4. Why is it that pilgrims or retreatants at Taize become much more part of the prayers in the church of reconciliation (definitely not mere spectators as in some other monasteries). Was it like this since the beginning?

5. The popularity of the unique music of Taize, more than ninety different editions published and compact discs distributed worldwide is amazing, why do you think is the music so popular?

6. Could you explain to me the Divine Office or liturgy, and the icons and the colours in the church of reconciliation?

7. What would you say is the purpose and function of the periodic Letter from Taize that Br. Roger writes and published in 58 languages?

8. Could you explain how Catholic and Protestant priests live together in this monastery in spite of theological differences? 


\section{Works consulted}

Capps, D 1998. Living stories: Pastoral counselling in congregational context. Minneapolis, MN: Fortress.

Casey, M 1994. The undivided heart: The western monastic approach to contemplation. Petersham, MA: St Bede's Publications.

Chittester, J 1990. Wisdom distilled from the daily: Living the rule of St Benedict today. San Francisco, CA: Harper \& Row.

De Dreuille M 2003. The columns of the benedictine spirituality. Bangalore: Asirvanan.

Deikman, A 1982. The observing self: Mysticism and psychotherapy. Boston, MA: Beacon.

De Waal, E 1989. Living with contradiction: Reflections on the rule of St Benedict. Collins: Fount.

Harris, C 1992. Relevant rituals. Ridgefield: Morehouse.

Jäger, W 1987. The way to contemplation. New York: Missionary Society of St Paul. Keating, T 1982. Open mind and open heart. New York: Continuum.

Keating, T 2003. Invitation to love: The eay of Christian contemplation. New York: Continuum.

Lukken, G 1999. Rituelen in overvloed: Een kritische bezinning op de plaats en gestalte van het christelike ritueel in onze cultuur. Baarn: Gooi en Sticht.

Malloy, P L 1998. The re-emergence of popular religion among non-Hispanic American catholics. Worship 72(1), 2-25.

Menken-Bekius, C 2001. Werken met rituelen in het pastoraat. Kampen: Kok.

Merton, T 1956. The sign of Jonas. New York: Doubleday.

Merton, T 1960. The wisdom of the desert. New York: New Directions.

Müller, J 1996. Om tot verhaal te kom: Pastorale gesinsterapie. Pretoria: RGN.

Nouwen, H J M 1975. Reaching out: The three movements of the spiritual life. New York: Image Books Doubleday.

Nouwen, J M 1990. The way of the heart. New York: Darton, Longman \& Todd.

Roberts, J 1994. Tales and transformations: Stories in families and family therapy. New York: WW Norton.

Scandrett-Leatherman, C 1999. Ritual and resistance: Communal connectivity in a church retreat. Missiology 27(3), 311-331.

Shea, S 1982. Storytelling and religious identity. Chicago Studies 21(1), 23-43.

Schutte, C H \& Dreyer Y 2006. An epistemological reflection on the relevance of monastic traditions for retreat in the Dutch Reformed tradition. HTS 62(3), 965-982.

Skar, H O 1985. Communitas and Schismogenesis: The Andean Pilgrimage Reconsidered. Ethnos 50(1-2), 88-102.

Steere, D V 1967. A fresh look at retreats. Religion in Life 36(1), 100-107.

Turner, V 1967. The ritual process: Structure and anti-structure. Chicago: Aldine.

Turner, $\vee$ 1972. Betwixt and between: The liminal period in Rites de Passage, in Lessa, W \& Vogt, C (eds), Reader in Comparative Religion, 234-245. New York: Harper \& Row.

Turner, V 1973. Symbols in African ritual. Science 179, 1100-1105.

Turner, V 1977. The ritual process: Structure and anti-structure. Ithaca, NY: Cornell University Press. 
Monastic retreat and pastoral care

Van Gennep, A 1960. The Rites of Passage, tr by M Visedom \& G A Caffe. Chicago, IL: University of Chicago Press.

Waaijman, K 2000. Spiritualiteit - vormen, grondslagen, methoden. Kampen: Kok.

Ware, C 1995. Discover your spirituality type: A guide to individual and congregational growth. Bethesda, MD: The Alban Institute.

White, M \& Epston, D 1990. Narrative means to therapeutic ends. New York: Norton. 